\title{
DE CHINEESCHE RAAD TE BATAVIA EN HET DOOR DIT COLLEGE BEHEERDE FONDS. ${ }^{1}$ )
}

\author{
DOOR
}

\author{
P. DE ROO DE LA FAILLE.
}

Van ouds heeft in Nederlandsch-Indië de Chineesche bevolking zich afgezonderd gehouden van den landzaat, steeds betrekkingen onderhoudend (zij het niet officieel) met het moederland, nieuwe krachten daaruit betrekkend, en in verschillende gevallen daarheen tijdelijk of blijvend terugkeerend.

Ofschoon zich aanpassende aan land en volk, bleef de Chineesche maatschappij door zeden en gewoonten, gedeeltelijk ook door taal en onderwijs zich scherp onderscheiden zoowel van de inheemsche als van de Europeesche ingezetenen, en om die reden min of meer als vreemdeling beschouwd, werd deze bevolkingsgroep, reeds vóór onze vestiging op Java, van oudsher door het Gezag verplicht om in eigen wijken te wonen onmiddelijk staande onder eigen, echter door de Overheid aangestelde hoofden, een toestand die min of meer ook onder ons bestuur van Batavia's stichting af tot op den huidigen dag behouden is gebleven.

Waar in artikel $73 \mathrm{R}$. R. gesproken wordt van het vereenigen der Vreemde Oosterlingen in afzonderlijke wijken, onder de leiding van hun eigen hoofden, die ter zake van de vereischte voorschriften worden voorzien, vormt evenwel een eigenaardigheid inzonderheid te Batavia het bestaan aldaar van ouds van

1) Aanvankelijk door de Ned. Ind. Commissie van Bijstand ter publicatie aan de Adatrechtcommissie h.t.l. opgezonden, volgt dit artikel, behoudens doorloopende herziening van den tekst, enkele verbeteringen en aanvullingen, op den voet eene nota, welke in 1917 de Ned.-Ind. Regeering door den steller in diens hoedanigheid van Resident van Batavia was aangeboden met het oog op een destijds in overweging zijnd plan tot opheffing op de drie hoofdplaatsen van Java van het oude instituut der Chineesche Officieren. 
een Chineeschen Raad, den zgn. Kongkowan, een erkend college, samengesteld uit de over deze natie staande hoogere hoofden, die de ouderwetsche titels van majoor, kapitein en luitenant dragen en zgn. wijkmeesters onder zich hebben. Luidens het Gouv. Besl. van 10 Februari 1868 №. 10 in Ind. St. No. 24, zooals dat is gewijzigd bij St. $1871 \mathrm{~N}^{\circ}$. 24, bestaat de Chineesche Raad te Batavia uit: één voorzitter, zijnde den majoor der Chineezen, tien leden, waarvan vier, en wel de oudsten van benoeming, den titel kapitein voeren, en acht luitenants, alsmede twee secretarissen.

Wat deze Chineesche Raad is, is niet in een woord te zeggen. De Regeeringsalmanak over 1924 dl. I blz. 130 bevat omtrent deze instelling, dat door dit college alle zaken van inwendig beheer worden geregeld en ter zake aan den Resident voorstellen worden gedaan. Toen in 1884 de toenmalige President der Bataviasche Weeskamer, de Heer Albrecht, de in Bijblad 4017 opgenomen nota over den staatsrechtelijken toestand der Chineezen in Nederlandsch-Indië schreef, teekende hij daarin aan : «Op de drie hoofplaatsen van Java vormen de gezamenlijke Chineesche Officieren den zgn. Chineeschen Raad Kongkowan, wien te Batavia afzonderlijke secretarissen zijn toegevoegd. Burgerlijke geschillen, welke volgens de godsdienstige wetten of oude herkomsten ter beslissing staan van hun priesters of hoofden, worden bij de Chineezen gebracht voor de Chineesche raden waar deze bestaan.» ${ }^{1}$ ) Deze omschrijvingen geven den toestand nogal juist weder. Op algemeen bestuursgebied verschaft de Chineesche Raad des gevraagd het Gewestelijk Bestuur inlichtingen, terwijl op klachten van Chineezen dikwerf het advies der Chineesche officieren wordt gevraagd. Deze officieren waren en zijn in zake Chineesche belangen voor het Europeesch Bestuur plaatselijke adviseurs en instrumenten, doch in den jongsten tijd is hun beteekenis verminderd, vooral sedert de Dienst voor de Chineesche Zaken, welke zich uitstekend heeft georganiseerd en toegerust, op den voorgrond is getreden, en

1) Vgl. artikel 78 R.R. alinea 2. Dergelijke zaken zijn, v.z.v. bekend, thans niet anders dan geschillen, waarbij echtscheiding wordt gevraagd. De Chineesche Officieren houden deze zaken liefst slepende om partijen in der minne weer tot elkaar te brengen; het schijnt, dat dgl. verzoeken meest het gevolg zijn van onheusche behandeling, welke de vrouw van de ouders van haar man ondervindt. 
over gansch Indië de algemeene leiding in handen heeft. Plaatselijk zijn de Chineesche Officieren echter nog steeds nuttige vertegenwoordigers van het locaal Chineesch element. Hun positie is van ouds een eervolle, doch niet sterke waardigheid, en in den jongsten tijd is dit instituut meermalen heftig aangevallen. De Chineesche Raad is als college naar buiten nauwelijks op den voorgrond getreden: de bemoeienis van dit College bestaat in het beheer van eenige specifiek Chineesche, plaatselijke instellingen, zooals de tempels en oude openbare begraafplaatsen. De politie en de aangelegenheden bij de bedrijfs- en inkomstenbelasting maken deel uit van het ambt der Chineesche Officieren doch de Kongkowan staat als college daarbuiten.

De samenstelling en taak van den Chineeschen Raad te Batavia wordt thans beheerscht door het voor dit College bij Res. besluit van 20 Augustus 1907 No, 15548/36 vastgesteld Reglement (Javasche Courant 30 Augustus 1907 No. 69) zooals dit is gewijzigd bij het besluit van 7 September 1915 No. 16210/6. In artikel 2 van dit Reglement wordt de werkkring van den Bataviaschen Chineeschen Raad als volgt omschreven: "De Chineesche Raad behartigt de belangen van de Chineesche gemeente te Batavia, draagt zooveel mogelijk zorg voor kosteloos onderwijs aan kinderen van onbemiddelde Chineezen, regelt en bekostigt de jaarlijksche openbare godsdienstige plechtigheden en voert het beheer over de Chineesche begraafplaatsen, welke gelegen zijn op de aan dien Raad toebehoorende gronden., Deze Kongkowan heeft eigen grondbezit bestaande uit een veertiental particuliere landerijen, in en om Batavia gelegen, terwijl ook het gebouw waarin de Chineesche raad zitting en kantoor houdt, dit College toebehoort. Het uit de inkomsten dier landen door hypotheekrente en grafgelden gevoed fonds van den Chineeschen Raad is bij lange niet onbeteekenend. Verder heeft de Raad in beheer vier eigendomsperceelen, waarvan drie ten name van Chineesche tempels en één ten name van de Chineesche Officieren.

De vraag, hoe de Regeering staat tegenover dit College en het daardoor beheerd waardevol. bezit aan geld en grond, stelt zich thans scherp, nu in overweging is genomen de herinrichting van het Chineesch bestuur ter hoofdplaats Batavia met afschaffing van het ambt van Chineesch Officier aldaar voor zooveel de taak dezer hoofden ligt op bestuursgebied. 
Dat de in de eigendomsakten ten name van de drie Chineesche tempels staande eigendommen aan deze als stichtingen toebehooren, lijdt wel geen twijfel. Zoo leest men in de Chineesche geschiedenis in T. N. I. III 1840, dl. 2 blz. 106 o. a. dat, "toen in 1790 het Gouvernement den tempel te Antjol wilde verkoopen, Ong Tjoe Seng de Chineezen aanspoorde om een inteekening te openen en den grond te koopen, ten einde den geest dien men daar vereerde te bevredigen, en een plaats te bezitten, waar bedestonden gehouden konden worden. Vervolgens werd er een hooge galerij gebouwd, tot rustplaats van een ieder, die hier een schuilplaats tegen de hitte wilde zoeken.»

Voor het overige, het meest beteekenend bezit zal tot beantwoording dier vraag het noodig zijn de geschiedenis van den Bataviaschen Chineeschen Raad en de verhouding hiervan tot de Chineesche begraafplaatsen op te halen. De bronnen vloeien niet overvloedig, doch uit oude Compagniesbeschikkingen en Hollandsche regeeringsgegevens benevens enkele Chineesche berichten ${ }^{1}$ ), vroeger reeds ten deele verwerkt in een bestuursnota van 1907, welke critisch in beschouwing is genomen door den toenmaligen Ambtenaar voor Chineesche zaken H. N. Stuart, valt voldoende bijeen te zamelen, dat inzicht in deze aangelegenheid verschaft.

Van den aanvang af heeft de Chineesche bevolking een door de V. O. I Comp. om haar nijveren en rustigen aard zeer gewaardeerd element uitgemaakt (vgl. artikel 74 van de Instructie voor Gouvernement en Raden van Indië in 1617; N. I. Plakaatboek I blz. 50). Evenals de gewone burgers droegen de Chineezen reeds terstond het hunne bij tot versterking der stad, te welken einde elk hunner ten overstaan van den Kapitein der Chineezen aangeslagen was voor zeker bedrag ten behoeve van de voltooiing van Batavia's verdedigingswerken (Pl. I ad 8 Mei en 2 Aug. 1623); ook hielpen zij bij de "stadswerken», en, toen Coen in 1620 (Pl. I blz. 59) het College van schepenen alhier instelde, nam "in saecken de Chineesen (onse ondersaten ende burgeren deser stede) concernerende" daarin zitting "Bencon, tegenwoordich opperste der Chineesen, behalve dat $\mathrm{d}^{\circ}$ Bencon in dit College niet en sal mogen presideren».

In de ommuurde stad Batavia bewoonden de Chineezen niet

1) Vgl. T. N. I 1840, $3^{\circ}$ Jaarg. dl. II en $1852,1^{\bullet}$ Jaarg. II. 
meer, zooals onder den Pangeran van Jacatra, uitsluitend hun eigen kwartier [destijds bij den mond van de Tjiliwoeng aan de Oostzijde van die rivier], maar woonden zij weldra door de heele stad verspreid, al groepten $\mathrm{zij}$ bij voorkeur langzamerhand vooral samen aan de westzijde ${ }^{1}$ ). Over deze in 1620 reeds 4 à 500 gezinnen tellende Chineesche bevolking stond als hoofd de zooeven genoemde So Bing Kong ${ }^{2}$ ), wien op zijn verzoek door Coen een plek grond op Manggadoewa ter woon was gegund ${ }^{3}$ ), vermoedelijk dezelfde tuin, waarin dit hoofd in 1644 is begraven.

Deze eerste Kapitein der Chineezen had met zijn landgenoot "Jancon", mede een vertrouwd koopman, het opzicht over de Chineesche speelbelasting [Pl. I 78/80]; zij waren tevens waagmeesters en mochten voorts looden "cassies ofte pitches» maken (I, 292). Hun landgenooten waren sinds 1620 aan een hoofdgeld onderworpen, bedragende oorspronkelijk $1 \frac{1}{2}$ reaal van achten per maand en per hoofd (tjap kaoe wang $=19$ dubbeltjes), tegen betaling waarvan deze Bataviasche Chineezen vrij waren aanvankelijk van diensten voor het Kasteel (I 76/77) en later zelfs van de schutterij (vgl. Van Diemen's Bataviasche Statuten Pl. I 547).

De stad bloeide door goeden handel en breidde zich uit; de opvolger van So Bing Kong, Bingam of Poa Benggang, zou de sluis bij Tangki hebben gebouwd en toegezien hebben op dwz. vermoedelijk hebben gepacht den aanvoer van hout en bamboe langs het Molenvliet bij de redoute Rijswijk (Pl. II blz. 351 en 355) en in verband daarmede schijnt hij te Krokot een zaagmolen ten dienste van de Comp. te hebben gehad.

Tijdens Poa Beng Gang kapitein was - die militaire titel staat waarschijnlijk in verband met de schutterij-instelling welk instituut aanvankelijk door Coen (Pl. I. 70/71, 95, 102-108) en later in de Bataviasche statuten was geregeld - vond in 1640 (Pl. I. 438) onder Van Diemen plaats de oprichting van het college van boedelmeesters voor Chineesche sterfhuizen [Pl. I blz. 438], een bewijs voor de beteekenis alstoen reeds van de Chineesche gemeente. Aan dit College werd weldra toegestaan

1) B. Hoetink, So Bing Kong, en J. W. Yzerman, Over de belegering van het Fort Jacatra B. K. I. 73, blz. 347, 352, 581.

9) Zie Hoetink, t. a.p. Voorts T. N.I. 1840 (2) blz. 13 en 15, en Ned. Ind. Plakaatboek I bl. 60 en 599.

s) T. N.I. III (2). 
[Pl. I 446] om ten behoeve van arme onverzorgde Chineezen een ziekenhuis op te richten op een door de Regeering geschonken, verlaten erf en daartoe eene "goetwillige collecte" te houden, doch al dadelijk blijkt meer noodig te zijn geweest, zoodat ten behoeve van dit ziekenhuis een heffing op de Chineesche begrafenissen werd ingevoerd; dit sgrafgeld 》 bedroeg in 1640 (Pl. I 454) $\frac{1}{2}$ reaal van achten benevens den $20^{\text {sten }}$ penning der nalatenschappen; alsmede werden aan dit hospitaal toegekend de boeten op niet-geautoriseerde Chineesche wajang-vertooningen.

In Van Diemen's Bataviasche Statuten van 1642 [Pl. I 472, zie bepaaldelijk ook blz. 525 en 546] waarin de plaatselijke bestuursinstellingen werden gecodificeerd en omtrent de Chineezen o. $\mathrm{m}$. werd verordend, dat zij voorhands bleven onderworpen aan hun "usantiën ende costuymen», vindt men bepaaldelijk ook de instelling van Boedelmeesters geregeld.

Wel is waar werd dit in 1640 ingesteld College van Boedelmeesters, de z.g.n. onchristelijke Boedelkamer, aldra in 1648 opgeheven, omdat de Comp. er geen nut van had en de Chineezen zelf dienaangaande veel moeite veroorzaakten, doch in 1655 werd het weer opnieuw ingesteld (besluit 3 Maart 1656), klaarblijkelijk om het toen weer erkend belang, en sindsdien werkt het college tot nu toe. Eigenaardig is het, dat dit college wel met de Chineesche begrafenissen [Pl. I blz. 526], doch niet met de Chineesche begraafplaatsen had uit te staan; dat laatste werd een zaak van de Chineesche gemeente zelf en hare officieren: van dezen tijd af ziet men te Batavia de zorg voor de belangen der Chineesche gemeente als het ware gedeeld tusschen de Chineesche officieren eener- en het College van Boedelmeesteren anderzijds.

Omtrent de Chineesche begraafplaatsen vinden wij in hun eigen locale kroniek aangeteekend, dat de teraardebestelling van den gewonen man destijds plaats vond op door de Comp. voor openbaar kerkhof aangewezen grond, terwijl de Chineesche Officieren werden bijgezet op eigen grond, Poa Beng Gang bijv. te Krokot, zijn «familiegoed». In 1660 verzochten de Chineezen onder den G. G. Maetsuijcker om voorbij het fort Jacatra een nieuwe begraafplaats aan te leggen, ${ }^{1}$ ) vermits de

1) Dit is vermoedelijk één der oudste stukken van de uitgestrekte Chineesche begraafplaats, welke bij Pintoe Besi Sentiong geheeten, zich zeer noordelijk uitstrekt (Sentiong beteekent nieuwe begraafplaats, en slaat $n$. $f$. eigenlijk op die, welke ongeveer in 1760 werd aangelegd). 
oude ${ }^{1}$ ) «t'eenemael met graven ende lijcken vervult was.»Daarbij werd ten behoeve van het Chineesche hospitaal de toenmalige belasting op de Chineesche begrafenissen van 2 realen gebracht op 3 rksd., en bepaald dat voor een Chineesch grafopschrift 12 rksd. zoude worden betaald (Pl. II 335). Waarschijnlijk van dit kerkhof verwierf 20 November 1668 (Pl, II 465) de Chineesche gemeente den eigendom tegen betaling van 400 rksd. (welk geld door de Regeering voor het Chineesche hospitaal werd bestemd); ter beveiliging tegen plundering door Amboineezen - ook scheen men daar van het kerkhof eigenmachtig aarde weg te halen - werd den Chineezen toegestaan een gracht rondom dit terrein te graven.

In 1666 overleed de Chineesche Kapitein Si Kwa lees: Gan $\mathrm{Dji} \mathrm{Ko}$, en nu naderde het tijdstip, waarop het bestuur over de Chineezen beter geregeld diende. Na Gan Dji Ko's dood was aanvankelijk het kapiteinschap 12 jaar waargenomen door zijn weduwe (een Balineesche bijvrouw), die krachtig het beheer over haar man's natie voerde, doch eerlang werd de stemming tegen dit vrouwenbestuur zoo sterk (Pl. III 6), dat in 1678 onder Rijckloff van Goens weer een kapitein werd aangesteld, n.l. de sedert 40 jaar te Batavia wonende, zeer geziene Tjoe Wa Njok lees: Tjoa Hiang Giok $^{2}$ ). Voorts werden dezen een Luitenant en een vendrig toegevoegd, onder toekenning aan dezen Kapitein van de bevoegdheid om - het begin van den Chineeschen Raad - met "communicatie zijner voorseijde twee minder officieren alle cleijne voorvallende zaken onder de Chinese burgerije alhier uijt onsen name aff te doen en te beslechten ende groote ofte andersints dubieuse te renvoyeeren daer 't behoort, mitsgaders verders alles te doen, wat een goet, vroom wacker capitein, overhooft en voorsprake toestaet ende betaemt».

De Chineesche gemeente, welke blijkens het vorenstaande dus al van belangrijke beteekenis was geworden, werd onder Camphuijs in 1690 door de instrooming van Chineezen uit hun vaderland, w. o. tal van personen zonder ambacht of nering, die zich wel eens aan "veele grove schelmstukken» schuldig maakten, zóó groot, dat zelfs de Chineesche Officieren beperking van dien

1) Op de kaart van Nieuhoff gelegen op den rechteroever van de Tjiliwoeng tusschen den Geldersohen weg en dien naar Antjol.

2) Deze zou uit China de 2 maal 's jaars rijpende "tongsan-padi" hebben ingevoerd op Java. 
toevloed verzochten. Alsnu volgde een plakkaat 21/29 Mei 1690 [P1. III 262], waarbij het jaar 1683 (herovering door de Mandsjoedynastie van het door den Chineeschen opstandeling Coxinga in 1663 op ons veroverde eiland Formosa) als fataal jaartal werd aangenomen: $1^{\circ}$ ter erkenning van de voor dien reeds gevestigde Chineesche ingezetenen, en $2^{\circ}$ voor de verplichte aanmelding der lateren, ter beoordeeling of dezen toegelaten konden blijven, terwijl bij dat plakaat almede regeling vond de toelating in den vervolge, verbod voor de "vreemde aankomende Chineesen" van vestiging ten platten lande, het invoeren van scherpe wapens enz. Met het oog op dit strenger toezicht werden alstoen in de stad Batavia "nevens de Nederlantse wijk ofte buurmeesters» ook «tweede off derde wijk ofte buurmeesters uijt de Chineesche natie» aangesteld enz., welke wijkmeesters jaarlijks door de Regeering op voordracht van schepenen werden benoemd (Pl. III 268 en 275).

$\mathrm{Bij}$ dit zelfde plakkaat werd voorts ingescherpt, dat Chineesche (ook Inlandsche) schuldbekentenissen door een Secretaris of Notaris moesten worden opgemaakt op straffe van nietigheid; eerst Staatsblad 1867 №. 29 hief deze beperking op.

Langzamerhand nam het Chineesch bestuur in gewicht toe, en met het oog daarop machtigde Van Outshoorn dan ook 4 October 1695 om aan den schrijver en den bode van de Chineesche Officieren te Batavia, tot dusver op dier kosten bezoldigd, 150 en 100 rksd. 's jaars toe te leggen uit de opbrengst der Chineesche wajangspelen ${ }^{1}$ ), waarvan het bedrag, ongeveer 400 rds. per jaar, was bestemd voor het Chineesch hospitaal.

In 1696/7 was met vergunning der Regeering door de Chineezen het kerkhof gekocht beoosten en bewesten den ouden loop van de Tjiliwoeng; hieromtrent werd in 1707 bepaald, dat zonder vergunning der Chineesche Officieren het laten weiden van buffels daarop was verboden, en dat bij het maken van

1) Valentijn IV blz. 251: als de Chineezen met een jonk of wangkang een behouden reize doen, dan zijn ze gewoon een wajang te geven. Dit is een Chineesch blij- of treurspel, hoedanige er op Batavia zeer veel gespeeld worden, en dat ieder hen omtrent honderd rijksdaalders komt te kosten, waarvan de Baljuw (zonder welkers verlof er geen spelen mag) zijne vaste voordeelen of 6 rijksd. van ieder heeft. Zij vermorsen jaarlijks wel 30 of 40.000 rds. daaraan, en geven in September, dat haar voornaamste hoogtijd ter eere van den Heere der aarde is, wel honderd wajangs, en in de maand er aan (zijnde de viertijd der dooden) weder wel even zooveel. 
graven aldaar, de aarde moest worden aangevoerd, instede dat de ophooging door vergraving van den kerkhofgrond zou geschieden. De boete à 10 rds was «ten behoeve van het aLazarushuis»» (Pl. III 583).

Toen in 1706 Van Hoorn ${ }^{1}$ ) de verbouwing van het Stadhuis te Batavia abuijten laste van de Comp. en de minste beswaringen der gemeente, wilde tot stand brengen, werd een fonds gevormd, waarbij werden gevoegd o.m. ^de 6000 rds. van onbekende Chinese erfgenamen, onder boedelmeesteren dier natie berustende, en voorts uijt de incomsten ende overgeschoten renten van dat collegie, boven d'ongelden, 1500 rds. des jaers, als dewelke volgens verklaringe van boedelmeesters buijten prejuditie der Chinese armen als andersints kunnen worden g'employeerd, aangesien de incomsten ordinair tusschen de 1500 à 2000 rds. meerder dan de ongelden komen te bedragen».

Niettegenstaande de beperkende toelatingsregeling groeide intusschen het aantal der Chineezen gestadig aan, dank zij de hulp hunner landgenooten, w. o. die van zelfs hun officieren: in 1706, vertelt Valentyn, kwamen er wel 27 à 28 jonken te Batavia aan, elk met 70 à 80 Chineezen en veel kostbaar goed aan boord. Wel werd in dat jaar [Pl. III 567] den Chineeschen schippers voorgehouden, dat voortaan een groote jonk niet meer dan 100 en een kleine niet meer dan 80 immigranten mocht aanvoeren, doch de Regeering betoonde zich vaak inschikkelijk in het belang van den handel, gelijk de G. G. M. de Haan later met nadruk aan Heeren XVII opmerkte.

De beduchtheid, die reeds zich openbaarde bij Van Riebeek en Van Swoll, was ten slotte in 1727 zóó geklommen, dat ${ }^{2}$ ) een der Chineesche schippers werd beboet met Rds. 3550, een 19-tal van de "swervende nieuwelingen benevens eenige inlandse vagebonden in de bovenlanden werden achterhaald en in de ketting geklonken om te worden versonden via Ceylon, Banda en de Caab, , en tenslotte streng toezicht werd gelast op de licentiebiljetten voor de Chineezen om in het binnenland als ambachtsman, landbouwer of handelaar werkzaam te zijn. Blijkbaar in

1) Van Hoorn - schreef Valentijn - „was zeer sterk voor de Chineezen"; repatrieerend nam hij in 1709 zelfs den te Batavia practiseerenden Chineeschen arts Tsieuw Bitja mede. Na Van Hoorn's kort daarop gevolgden dood is deze weder naar Batavia teruggekeerd.

3) De Jonge, Opk. IX bl. 126/7 en Plakaatb. IV bl. 198. 
verband daarmede vindt men het aantal Chineesche Officieren vergroot, in 1729 zelfs gebracht op zes personen. In Valentyn's tijd woonde de Kapitein der Chineezen buiten de Nieuwe Poort, en den eersten van elke maand liet dit Chineesche opperhoofd van een hoogen steng voor zijn huis een groote witte en roode vlag waaien ten einde zijn landgenooten indachtig te maken aan hun betaalplicht: ieder Chinees die een kondé "of hair in tuiten rondom tegen 't hoofd gelegt» droeg, betaalde 38 stuivers, een "Tartar, die een tuit droeg», 1 gulden, welk hoofdgeld de Bataviasche Chineezen "tocht- en wagt-vrij, maakte.

De Chineesche Officieren ziet men af en toe zich met klachten of verzoeken wenden tot de Regeering, en soms worden zij met Boedelmeesteren over te nemen verordeningen geraadpleegd: in 1717 bepaalde Van Swoll ter voorkoming van "misbruyk ende onordentelijkheden" dat Chineesche huwelijken en echtscheidingen moesten plaats vinden ten overstaan van de hoofdofficieren dier natie (PI. IV 94) en onder $Z$ waardecroon kwam na hunlieder overleg een nieuwe regeling tot stand op de erfenissen $\mathrm{ab}$ intestato onder de Chineezen.

In de eerste helft van de XVIIIe eeuw neemt de Chineesche gemeente te Batavia in getal en rijkdom sterk toe; haar officieren leven niet alleen van den handel, maar ook van den landbouw. Zij zijn groot grondbezitters tevens soms zeer gewaardeerde suikermolenaars ${ }^{1}$ ) en arakstookers te wier gerieve de toelating van Chineesche immigranten wordt verzocht. $\mathrm{Zij}$ staan bij de Regeering ${ }^{2}$ ) in aanzien, en zulks niet alleen om de gebruikelijke geschenken, welke deze Officieren bij hun aanstelling, Nieuwjaar enz. plachten op te brengen ${ }^{3}$ ). Ter tegemoetkoming in hun verplichte uitgaven vinden wij in 1738 medegedeeld ${ }^{4}$ ) dat "weder als voorheen aan de officieren van de Chineesen voor 650 Rds. ter maand» was afgestaan de pacht van de waag.

1) De Jonge, Opk. VIII bl. 157 (1711), IX 73 en 85 .

2) Om de curiositeit wordt hier aangestipt dat uit de nalatenschap van den in 1729 overleden landvoogd M. de Haan een som van niet minder dan 3442 rds. moest worden uitgekeerd aan zekere Chineesche doctoresse voor gepresteerde diensten en geleverde medicamenten gedurende den tijd van 30 jaren (Pl. IV 300).

s) Nog tot 1797 [Pl. XII blz. 445] ontving de G. G. van Overstraten geregeld van den Kapitein-Chinees tot tafelgeld 's maands Rds. 400, en tot een nieuwjaarsgeschenk Rds. 1000.- (vgl. de Javaansch-Vorstenl. bekti enz.). Zie ook T. N. I. 1852, 14 e Jaarg. II blz. 5 noot $(\dagger)$.

4) De Jonge, Opk. IX blz. 277. 
In de stad Batavia bleef die Chineesche natie steeds een bijzonder element vormen, waarmede afzonderlijk goed rekening werd gehouden. Zaten in het College van Schepenen steeds twee Chineesche leden, zaken meer in het bijzonder het bestuur rakend, kwamen langzamerhand al meer op de Chineesche officieren neder. Dezen waren het, die tusschen Chineezen onderling kleine zaken afdeden, de bijzondere belastingen inden, collecten aanvroegen voor de instandhouding der kerkhoven enz., en verder in het algemeen de belangen van hun volk voordroegen. Intusschen bleef naast deze hoofden in functie het stedelijk college der Boedelmeesteren ${ }^{1}$ ), dat mede zorg droeg voor het Chineesche hospitaal, en in die hoedanigheid zelfs toezicht hield op een Chineesche schooI voor arme kinderen, welke in 1737 was geopend in een huis aan de Noordzijde van dat ziekenhuis (Pl. VI, 535). In hoogste instantie ging boven deze, in de stad Batavia haar eigen leven levende Chineesche gemeente, de Hooge Indische Regeering, toezicht houdend, regelend, instellend en zelfs op aanvragen voor collecten beschikkend, naar wier bevelen de Chineesche gemeente zich schikte of wier sanctie op eigen regelingen door haar werd verzocht.

Dan vindt plotseling maar niet onbegrijpelijk ${ }^{2}$ ) plaats de verschrikkelijke Chineezenmoord van October 1740. In zijn gevolgen is deze gebeurtenis voor het bestuur over het Chineesche element van groot gewicht geweest. Aanstonds werd het College van Boedelmeesteren van zoo "grooten omslag en verantwoording" dat het versterking behoefde ( $\mathrm{Pl}$. IV 520, 526 en 531) en het aanzien daarvan officieel werd verhoogd. Maar het gewichtigst is wel, dat van dien tijd dagteekent de opzettelijke aanleg van een Chineesche wijk te Batavia, buiten de muren der toenmalige stad (De Jonge, Opk. IX blz. LXX), de latere zgn. kamp bij Glodok. De moord had plaats gevonden onder den indruk, dat de ten platten lande rondzwervende, de stad bedreigende Chi-

${ }^{1}$ ) In 1724 bestond dit college uit drie Europeesche leden (w. o. de voorzitter en ondervoorzitter), drie Chineesche leden en éen Europ. Secretaris.

2) Vgl. over de beduchtheid voor het groot aantal vagebonden, w. o. Chineezen, die zioh schuldig makten aan „stelen, rooven en moorden", de G. G. M. de Haan, bij De Jonge, Opk. IX blz. 126. Zie ook Valentyn IV blz. 250. Over de rooverbende van Kim-Tiaoe-Boeij in 1731 de Chin. Chronol. Gesch. in T. N. I. $18403^{\circ}$ Jaarg. II blz. 47. 
neesche benden opstandelingen verstandhouding onderhielden met de groote Chineesche gemeente binnen de stadsmuren, en het gevolg van dien toenmaals nog sterk heerschenden angst is geweest, dat het vreemde element voortaan buiten de eigenlijke stad een woonplaats werd ingeruimd ${ }^{1}$ ). Die wijk is gebleven, echter werd onder Van Imhoff eerst den Chineeschen Officieren (PI. V 75) en later ook aan anderen weer vergund om in de stad te wonen.

Langzamerhand trad trouwens met de teruggekeerde orde ook blijkbaar een geneigdheid aan den dag om tegenover de Chineesche gemeente of liever haar Officieren het een en ander goed te maken. De Kapitein-Chinees kreeg een toelage en een Chineesch Raadhuis werd ingericht: uit het kapitaal der Boedelkamer een huis met de daarbij behoorende opstallen, staande in de Zandzee, voor 12500 rds. gekocht ter bewoning door de opvolgende Kapiteins der Chineezen [zij zouden 's jaars $4 \frac{1}{2}$ procent van de koopsom voor het gebruik aan Boedelmeesteren betalen en de herstellingskosten van het huis zelf dragen (Pl. V 465/6)], en van dit oogenblik - de oprichting van deze Roemah bitjara ${ }^{2}$ ) dagteekent de Chineesche plaatselijke geschiedenis het bestaan van den Chineeschen Raad, den z.g.n. Kongkowan.

Chineesche Raad en College van Boedelmeesteren hadden elk hun eigen taak, hun eigen fonds; toch ging ook wel eenige stuwkracht uit van den Chineeschen Raad ten behoeve van Boedelmeesteren met betrekking tot het Chineesche hospitaal.

In 1747 bijv. verzochten de gezamenlijke officieren van de Chineesche natie aan de Regeering een nieuwe regeling van de inkomsten voor het Chineesche hospitaal; wel is waar waren begrafenisgelden ingesteld, doch de meeste hier overleden Chineezen werden "ten laste van die van hun natie ter aarde gebracht», zoodat die heffing weinig geld inbracht; instede daarvan werd daarom thans een heffing op het trouwen ingevoerd ten behoeve van het Chineesche hospitaal ten bedrage van 3 rds. voor gewone Chineezen en van 8 rds. voor de Officieren, benevens de $20^{\text {ste }}$ penning voor alle erfenissen. (Pl. V. 497).

Ten aanzien van de Chineesche begraafplaatsen, die onder het beheer stonden van den Kongkowan, vermeldt nu de Chi-

1) De Jonge, Opk- $\mathrm{X}$ blz. 155.

2) In de kampong Malacca Tiang Bandera, welke naam doelt op den vlaggestok, vanwaar de kapitein der Chineezen gedurende de drie eerste dagen eener maand een vlag liet waaien: vgl. Pl. V blz. 110. 
neesche geschiedenis van Batavia (T. N. I. III 2. blz. 81): «In het jaar 1745 raadpleegde de Kapitein-Chinees Lim Heng Kong met zijne Luitenants nopens het aanleggen van een nieuw kerkhof. Bij inteekening een som gelds verzameld hebbende, kocht hij het Japansche paviljoen en een tuin, behoorende aan een Raad van Indië, zich uitstrekkende tot Kamajoran ${ }^{1}$ ), om daarvan een lijkveld te maken», en in het volgende jaar werd genoemde Kapitein-Chinees ook op dit kerkhof van het Japansche paviljoen begraven.

Verder lezen wij: «in het jaar 1760 raadpleegde de KapiteinChinees met zijn Luitenants over het aankoopen van een nieuwen doodenakker; zij noodigden al hun landgenooten uit om daarvoor in te teekenen, ten einde den Gouvernementstuin te Golongsali (Goenoengsari) te verkrijgen, waar een budhisten-tempel was met een menigte steenen beelden, vroeger door Chineezen vervaardigd».

Hier is blijkbaar bedoeld dat deel van het Chineesche kerkhof bij Pintoe-Besi, waar het oude landhuis, dat zgn. aan den Gouverneur-Generaal van Imhoff, doch zeker aan Mossel toebehoord heeft ${ }^{2}$ ) en thans nog tempel is, zich bevindt met het daarnaast liggend aschhuis. Men krijgt den indruk dat het thans nog bestaand Sentiong een steeds aangewassen complex is van successievelijk verworven Chineesche kerkhoven.

In de nieuwe statuten van Batavia van 1766 komt onder het hoofd «keuren» op de begrafenissen en begraafplaatsen voor:

3. De Chineezen mogen hun dooden begraven boven en bewesten ' $t$ fort Jacatra, mits alle dezelve twee malen in ' $t$ jaar van ruijgte, vuijligheid en doode krengen zuijverende, waarop Heemraden de vereischte toezigt moeten houden.

4. Onder de gepermitteerde plaatsen is egter, met relatie tot het te dien eijnde door haar bezeeten wordende stuk lands, Goenoeng Sahari genaamd, niet begreepen het geene bewesten of zuidoosten van de oude loop der Groote rivier legt, als zijnde wel expresselijk verbooden daar eenig lijk te begraaven, op verbeurte van 't land selve, ten behoeve van de Compagnie».

1) Dit Kamajoran draagt vermoedelijk zijn naam naar den titel van Isaac de l' Ostal de Saint Martin, grootgrondbezitter tevens oud-Garnizoenscommandant en oud-Raad van N. I., overleden 1696; Priangan I, Personalia blz. $15 \mathrm{vlg}$.

2) Dr. F. de Haan, Priangan dl. II blz. 511 volg. 
In de nieuwe statuten van Batavia van 1766 vindt men het te Batavia tot op dien datum verordende, voor zoover niet opgeheven, samengevat (Pl. IX).

Betreffende 1791 ( $\mathrm{Pl}$. XI 357/8), toen Batavia reeds in verval kwam en de handel zeer verslapt was, vinden wij in het Plakaatboek opgeteekend, dat Boedelmeesteren alstoen wisten gedaan te krijgen, dat ter zake van het in 1747 in gebruik gegeven vergaderhuis, de Roemah Bitjara, door den Kapitein-Chinees en zijn opvolgers in payementen van 5000 rds. de oude koopsom van 12.500 rds. aan het College zou worden terugbetaald ${ }^{1}$ ) (Pl. XIV 34).

In 1804 werd onder Siberg herzien de regeling op de toelating van Chineezen; uit de toelatingsgelden werd een gedeelte toegekend o. a. aan het Chineesch hospitaal.

Men is dan in de oorlogsjaren en de welvaart verminderde zienderoogen, ook in de Chineesche gemeente ${ }^{2}$ ). Het fonds van Boedelmeesteren geraakte daardoor in moeilijkheden, o. a. in verband met de groote kosten van het Chineesch hospitaal. In 1805 (Pl. XIV, 218) werden onder Wiese geregeld de boeten bij Chineesche huwelijken en begrafenissen ten voordeele van de kas van Boedelmeesteren; onder denzelfden Gouverneur-Generaal werd in 1807 al verder tijdelijk aan dit college gegund $\frac{1}{4}$ van de wajangpacht, en werd dit gemachtigd van onbekende erfgenamen aangehaalde gelden bij de renten te voegen (onverminderd bevoegdheid der Reg. om bij reclame nader te disponeeren), maar nog in 1808 gelastte Daendels Boedelmeesteren het jaarlijksch deficit aan de Regeering kenbaar te maken, sten einde door de van de zijde dezer Regering te nemen maatregelen, overeenkomstig de billijkheid, daartegen te kunnen voorzien» (Pl. XIV 669).

Het Chineesch hospitaal bleef een belangrijke instelling. Aldaar praktiseerden (Pl. XV 667) de Stadsdokter en Chirurgijn (uit de

1) Hierdoor werd dit huis mitsdien Chineesch eigendom, en het schijnt dan ook dat sedert de Chineesche Raad vergaderde ten huize van den hoogsten Chineeschen Officier.

2) Zie Plakaatb. XIV 167. Dit is ook de reden geweest, dat in 1808 moest worden afgezien van de poging om door de oplegging van een Chineesch hoofdgeld de aan de Chineesche Officieren toe te kennen inkomsten goed te maken. Later heeft dit hoofdgeld te Batavia en Samarang bestaan ten behoeve der met de politie over hun landgenooten belaste Chineesche hoofden (C. S. W. van Hogendorp, Beschouwing, enz. blz. 136); in 1829 vervangen eerst door de huistaks en alras door de bedrijfsbelasting.

Dl. 80 . 
kas van Boedelmeesteren van het Chineesche hospitaal werd daartoe 800 rds. bijgedragen), en tot ondersteuning van deze instelling legde maarschalk Daendels den Chineeschen Officieren bij hun aanstelling de storting in eens van belangrijke geldsommen op, dezelfde bedragen, welke vroeger in den vorm van geschenken aan Gouverneur Generaal, Gouverneurs en residenten plachten te worden opgebracht (Pl. XY 929).

De naam Chineesch hospitaal was intusschen niet meer eigenlijk. Wij vinden toch dat onder Daendels aldaar werden verpleegd mede "zieke kettingmeiden» en "koelies» (Pl. XV. 8. 53 en XVI 644), als ook andere Vreemde Oosterlingen, Mooren enz.; in 1810 bedroeg dit aantal 151 personen, Chineezen en Inlanders (Pl. XVI, 66). ${ }^{1}$ )

In 1810 (Pl. XVI, blz. 38) autoriseerde Daendels het Collegie van Boedelmeesteren de kas van het Chineesch hospitaal voortaan gescheiden te houden van die van de Inlandsche Weeskamer en deze landvoogd regelde alstoen daarbij de inkomsten van dat hospitaal opnieuw. Deze zouden bestaan, behalve uit de door de Chineesche Officieren op te brengen aanstellingssommen, uit «trouwbrieven aan Chineezen, boeten op buitengewone begrafenisplechtigheden zoomede op het vergrooten der Chineesche begraafplaatsen, de collaterale gerechtigheid» enz. enz.

Onder het Staatsbestuur namen de zaken sedert den volgenden loop.

- Toen - leest men in het door den toenmaligen Secretaris van het Gouvernement J. C. Baud opgesteld Berigt rakende het fonds der Chineesche graven (bijlage van den brief van de Algemeene Rekenkamer van den $15^{\text {den }}$ October $\left.1816 \mathrm{~N}^{\circ} 7\right)-$ de Generaal Daendels in 1809 het alleszins nuttig plan vormde om de Chineesche begraafplaats, gelegen te midden van het sierlijkste en gezondste gedeelte der Voorsteden, te doen slechten, werd het noodig den Chineezen een ander stuk gronds aan te wijzen, alwaar zij, zonder de gezondheid van de Europeesche inwoners hinderlijk te zijn, de spoedig in stinkpoelen veranderde kuilen konden graven, welke tot het vormen van een Chineesch graf onontbeerlijk zijn. Men vestigde, tot dit einde, het oog op

1) Tot 1882 toe werden te Batavia in het Chineesch hospitaal ook Inlandsche krankzinnigen verpleegd, sedert overgebracht naar Buitenzorg. 
een bewesten de stad gelegen stuk land, Tandjong ${ }^{1}$ ) genaamd, en bij besluit van 26 October 1809 werd bepaald, dat de som van 70.000 Rijksdaalders, tot dezen koop benoodigd, door de Weeskamer, onder borgtocht der voornaamste Chineezen, tegen een interest van zes ten honderd 's jaars zoude worden voorgeschoten, en dat deze som bij jaarlijksche termijnen zoude worden afgelost, door middel van zekere betalingen, welke, naar evenredigheid der grootte, voor elk graf werden vastgesteld. $\mathrm{Na}$ de geheele afbetaling zoude deze nieuwe begraafplaats het eigendom wezen van de gezamenlijke alhier wonende Chineezen (Pl. XV, 908/911).

In 1814, ter gelegenheid van eenige ingekomen klachten enz. over partijdigheid van den Kapitein Chinees in het uitdeelen der stukjes grond, voor graven bestemd, werd van Gouvernementswege een onderzoek begonnen, in den loop van hetwelk men ontwaarde dat de schuld aan de Weeskamer toen nog 15.000 Rijksd. bedroeg, en dat de kapitein Chinees toen reeds een beloop van 23.286 Rijksd. 26 St. voor rekening van het kerkhof in handen had. Hem werd terstond gelast de geheele aflossing van de hypotheek te laten gevolg nemen, en sedert dat tijdstip is het nieuwe verkregene Chineesche kerkhof dus Chineesch eigendom, en het dagelijks inkomende gravengeld, dat in sommige gevallen 3600 Rijksd. voor een graf beloopt, strekte alleen tot vermeerdering van een fonds, waartoe destijds nog geen bepaald einde was aangewezen. Men vroeg den Kapitein Chinees wel is waar af wat hij nu met dit geld dacht aan te vangen, doch zijn antwoord: "dat hij het fonds tot verbetering der wegen, bruggen en gebouwen, bij het kerkhof behoorende, zoude aanwenden, en in het vervolg van tijd, de arme Chineezen geheel en al van het betalen van gravengeld zoude verschonen, kon - schreef Baud - niet als een, aan onveranderlijke bepalingen onderworpen doeleinde worden aangemerkt.

Toen het Gouvernement zich in Januari 1816 onledig hield met de verbetering van het fonds van het Chineesche hospitaal, bepaalde Hetzelve dat van dit bovengenoemde gravengeld de helft zoude worden betaald voor dit gesticht, en het overschot

1) Dit is het thans nog aan den Chineeschen Raad behoorend perceel Tandjoeng-Lengkong dat in 1828 vergroot is met het alstoen tot uitbreiding der begraafplaats à f 15.000 (met van de Boedel-en Weeskamer geleend geld) gekocht land Salipi. 
blijven ter dispositie van den Kapitein Chinees, tot het door hem opgegeven einde».

De Algemeene Rekenkamer deelde omtrent die quaestie het volgende mede.

- Het onderhoud van het Chineesche hospitaal, waarin zieke en krankzinnige Chineezen, Inlanders en andere onchristenen gehuisvest werden, vond onder het Hollandsche Gouvernement plaats uit een fonds onder beheer van Boedelmeesteren, spruitende uit de verpachting der wajangs- en top-spelen, waarvan aan het Hospitaal een derde werd uitgekeerd.

Onder het Britsch Gouvernement werden de topbanen echter verboden ${ }^{1}$ ), en werd het wajang-vertoonen ten behoeve van 's Lands kas verpacht ${ }^{2}$ ) zonder toekenning van bedoeld aandeel aan het Chineesch Hospitaal, en het gevolg van een en ander was, dat het fonds voor die stichting bijna geheel te niet geraakte.

Bij publicatie van 26 Januari 1816 werd alstoen door den Lieutenant Governor in Council besloten, sthat on all payments made for portions of the Chinese burial grounds according to the Regulations of the former (i.e. -Dutch) Government issued in the year 1809, one half shall be paid to the Native Orphan Chamber on account of the Chinese Hospital and on the other half shall continue to be paid to the Fund for care and preservation of the Burial Grounds itself».

Bij publicatie van 2 Februari 1816 werd verder nog bepaald, dat het aan het Gouvernement vervallende aandeel van alle boetens, ontvangen wordende zoo door de onderscheidene Hoven van Justitie en Magistrature als door het Revenue-Komittee, ingevolge de bestaande wetten en Reglementen, voortaan alle drie maanden zal gestort worden in de schatkist van het Kollegie (van Boedelmeesteren) ten einde deszelvs Fondsen te verbeteren en de onkosten van het onder deszelve toezicht staande Inlandsche Hospitalen te helpen bestrijden".

Deze regeling werd in 1816 bestendigd (B. 27 Oct. 1816 No. 6) en het niet specifiek Chineesch-gemeentelijk karakter van dat hospitaal blijkt alweder, waar men vindt medegedeeld ${ }^{3}$ ) dat in 1824 , toen door de bouwvalligheid der lokalen eene geheele

1) Benevens de hanenvechterijen; Levyssohn Norman, De Britsche Heerschappij blz. 245/6.

?) T. a, p. blz. 257.

s) C. S. W. van Hogendorp, Beschouwing enz. blz. 334. 
vernieling dreigde, het Gouvernement de kosten der voornaamste herstellingen op zich nam en aldus dit gesticht als het ware geheel op nieuw oprichtte.

In 1828 werden de functiën van het College van Boedelmeesteren, waarvoor bij besl. Comm. Gener. ddo. 31 Mei 1828 No. 30 (Staatsblad No. 46) een Reglement werd vastgesteld, opgedragen aan de Weeskamer, die daartoe werd aangevuld met eenige Chineesche en Arabische leden, eene inrichting die tot op heden voort bestaat.

Dit College is een Landsinstelling; wel is waar in het bezit van een eigen fonds, maar rekenplichtig aan de Rekenkamer en geheel beheerscht door de door den gewonen wetgever vastgestelde evengenoemde instructie, terwijl processen (tenzij voor zooveel afzonderlijk bepaald) niet «dan op autorisatie der Indische Regeering " mogen worden gevoerd (artikel 58).

Dit College was toen nog belast met «de directe administratie van het Chineesche hospitaal», tot bestrijding van welke inkomsten tal van heffingen waren aangewezen (vgl. artikel 64 van het Reglement en St. 1828 No. 26 ad ten tweede, ten derde en ten vijfde, gelijk ook St. 1828 No. 55 Ten Tweede), welke inkomsten afgescheiden waren van het eigen fonds der Boedelkamer.

Opmerking verdient, dat het fonds van het College krachtens artikel 64 sub $k$ mede de helft genoot van het inkomen van den verkoop van Chineesche graven, gelijk zulks in den jare 1815 was bepaald, met en benevens de daarop volgende boeten, terwijl de wederhelft zou moeten strekken - vindt men daarbij bepaald - "tot onderhoud van het Chineesche kerkhof enz. enz.»

De wederhelft kwam alzoo ter beschikking van den Chineeschen Raad voor de door dit College beheerde (in eigendom door de Chineesche gemeente bezeten) openbare Chineesche kerkhoven.

Onder den G. G. Van der Capellen, die zich veel gelegen liet liggen aan het op ruime en gezonde wijze herbouwen van de stad Batavia te Weltevreden, werd - vinden wij medegedeeld door C. S. W. van Hogendorp in diens Beschouwing enz. (blz. 317) - aan de Chineezen verboden, voortaan hunne dooden op de oude lijkvelden te begraven, en in plaats daarvan, werd hun aan den weg van Grogol zeer ver van de woonplaatsen der Europeanen een nieuw grafveld aangewezen. In 1828 , werd tot uitbreiding van de algemeene begraafplaats op het land Tandjong aangekocht het aangrenzend Salipi. Dit 
geschiedde met de bij de Boedel- en Weeskamer opgenomen som van $f 5000+f 10.000=f 15.000$ rentende ${ }^{3} / 4 \%$ 's maands. Dit perceel werd ingeschreven op naam van den Chineeschen Raad, en wel is waar heeft in 1852 het College van Boedelmeesteren geageerd tegen de Chineeschen Raad om dit College veroordeeld te krijgen tot het doen aan de Boedelkamer van rekening en verantwoording en het storten van het voordeelig saldo in de kas van dat College, doch bij vonnis van den Landraad der Stad en Voorsteden van Batavia ddo. 7 Maart 1853 No. 27 (ten slotte bekrachtigd bij het arrest van het $\mathrm{H}$. Gerechtshof 10 Juni 1853) is die eisch ontzegd geworden.

Vermoedelijk heeft dit rechtsding de aandacht van het Bestuur er op gevestigd, dat op bedoeld door den Chineeschen Raad beheerd fonds eigenlijk geen toezicht werd uitgeoefend; in 1853 ten minste maakte de toenmalige Resident van Batavia deze zaak aanhangig.

Door aankoop - berichtte dit Bestuurshoofd - was de Chineesche Raad te Batavia eigenaar van de in de Ommelanden van Batavia gelegen landen Tandjong en Slipi, bestemd tot Chineesche begraafplaats, en volgens de van het beheer dezer landen gehouden boeken bedroeg het saldo daarvan in 1854 $f 47.000$, welke som bij den Majoor der Chineezen te Batavia Tan En Goan berustte zonder dat eenige andere controle bestond, dan dat deze nu en dan een rekeningcourant aan den Chineeschen Raad overlegde.

In overleg met dit College en den Majoor werd daarop door den Resident eene regeling getroffen, tot vaststelling waarvan (na regeling, bij notarieele overeenkomst, van de door den Majoor-Chinees gevoerde administratie van de landen Tandjong en Slipi van 1829 af) genoemd Bestuurshoofd werd gemachtigd bij het G. B. van 17 Juli 1855 No. 3 .

De Procureur-Generaal Mr. Hoogeveen, in wiens brief mede gewag werd gemaakt van den toen aanhangigen aankoop van het land Djati, had daarbij aangestipt dat een regeling diende getroffen voor de beschikking over de inkomsten, meer bedragende dan het onderhoud van wegen en bruggen op die landen.

Bij G. B. van 17 Februari 1856 No. 23 werden de door den Resident ter zake verrichte handelingen goedgekeurd \&met bekrachtiging van het (door dezen vastgesteld) reglement voor het beheer van het Chineesch begravenisfonds te Batavia». 
Bij artikel 9 van dit Reglement was bepaald «dat de opbrengsten der aan het fonds toebehoorende landen, met uitzondering van die wegens den aankoop van graven, jaarlijks - voor zoover ze niet reeds zijn verhuurd - aan den meest. biedende onder solide borgtocht in het openbaar zullen worden verkocht». Bij G. B. 4 Februari 1858 No. 29 werd deze bepaling aldus aangevuld:

«Bijaldien eene verpachting, voor langer dan één jaar, in het belang van het fonds, den Chineeschen Raad wenschelijk voorkomt, zal daartoe door den Resident vergunning kunnen verleend worden, mits de termijn van vijf jaren niet worde overschreden *.

In dit Reglement was voorts bij artikel 6 bepaald:

-Ten laste van het fonds worden gebragt de gewone onkosten wegens het onderhoud der graven, zoomede de uitgaven voor de gebruikelijke godsdienstige feesten bij de begraafplaatsen. Ook komen nog ten laste van het fonds de uitgaven wegens bezoldiging van eenen mandoer, die met het toezigt over de graven belast is. Het bedrag dier bezoldiging bepaalt de Chineesche Raad».

Sedert werd echter met toestemming van de Regeering (G. B. 2 Aug. $1861 \mathrm{~N}^{\circ}$. 35) uit dit fonds mede bekostigd de aankoop van het nog bestaande Chineesche Raadhuis, hetwelk tot dusver bij de Kongkowan in huur was en in eigendom toebehoorde aan den Kapitein der Chineezen Ko Tjoen Kiat. De Chineesche officieren hadden hiermede een behoorlijk onderdak, te meer geëigend, waar bij G. B. van 3 Mei $1860 \mathrm{~N}^{\circ}$. 47 de Chineesche Raad als een openbaar lichaam was erkend, hetgeen mede blijkt uit St. $1868 \mathrm{~N}^{\circ} .24$ zooals dit gewijzigd en aangevuld is bij St. $1871 \mathrm{~N}^{\circ} .70$.

Ten slotte dienen nog twee feiten te worden vermeld.

In de eerste plaats, dat onder den Resident Hofland bij Residentsbesluit van 20 Aug. 1907 No. 15548/36 (Javasche Courant 30/8 1907 No. 69) een nieuw Reglement voor den Chineeschen Raad te Batavia op voordracht van den Assistent Resident en gehoord den Ambten. van Chineesche Zaken in overleg met den Chineesche Raad is vastgesteld, - welk reglement, dat heden ten dage nog van kracht is, beoogt om «nu de Chineesche Raad alhier eenmaal bestaat, de bevoegdheden en verplichtingen daarvan binnen de perken der wet administratief 
te regelen en den Raad zoodoende onder Europeesch bestuurstoezicht te brengen».

In de tweede plaats verdient vermelding dat het onder het College van Boedelmeesteren ressorteerend, uit den ouden tijd stammend zgn. Chineesch hospitaal te Batavia, met de gelijksoortige gestichten te Semarang en te Soerabaja in 1911 bij St. No. 585 is opgeheven, aij het met instandhouding dier instellingen voortaan als Landsinrichtingen in den vorm van een hulpstandsverband te Batavia en Semarang en te Soerabaja van een leprozen-gesticht, terwijl bij artikel 2 van St. 586 van datzelfde jaar o. m. de oude bepalingen (vgl. B. B. 4017 blz. 29) nopens' de fondsen tot instandhouding, vervat in artikel 64 van St. 1828 No. 46 (zooals dit sedert was aangevuld) alsmede de zegelbelasting op de aanstellingsakten der Chineesche Officieren (St. 1819 No. 32) werden ingetrokken. Het aan het Chineesch hospitaal te Batavia verbonden Particulier land Angke-Kapoek, even ten Westen der hoofdstad gelegen, werd alstoen bij het Landsdomein getrokken en daarop is bij St. 1914 No. 315 de landrente-belasting ingevoerd.

Deze inlijving van Angke Kapoek wordt in de Chineesche gemeente, naar het schijnt, wel beschouwd als een onrechtvaardige daad van het Gouvernement, maar ten onrechte. Duidelijk toch blijkt het Chineesch hospitaal hoe langer hoe minder een specifiek Chineesch-gemeentelijk karakter te hebben gedragen. Deze instelling is oorspronkelijk op voordracht van Boedelmeesteren in het leven geroepen door de Regeering en het eerste gesticht kwam te staan op door de V. O. I. C. geschonken grond, terwijl het later met Gouv. hulp hersteld tweede gebouw ${ }^{1}$ ) voor welks onderhoud o. m. Angke Kapoek heeft gediend, wel bekostigd is gedeeltelijk uit de middelen van Boedelmeesteren, gedeeltelijk uit bijdragen der Chineesche gemeente, doch al zeer spoedig uitdrukkelijk bestemd is geworden in het algemeen voor niet-Europeesche onvermogende zieken. Het feit dat oorspronkelijk voor de inrichting van dat ziekenhuis oudtijds een "goedwillige collecte, onder de Chineesche gemeente is gehouden, doet tot het wezen der zaak niet af, te minder waar overtuigend blijkt dat de instandhouding voortaan geschiedde door van Regeeringswege al naar de behoefte verordende en geregelde heffingen, en over de opneming van per-

1) Vgl. Oud-Batavia (deor Dr. F. de Haan) Gedenkboek, I $\$ 637$. 
sonen (behalve Chineezen ook Inlanders en Mooren) van Overheidswege regelen waren gesteld, zoodat het Chineesch hospitaal geheel als een openbare landsinstelling was te beschouwen. Minstens sedert het begin der $19^{\mathrm{e}}$ eeuw droeg het zgn. Chineesch hospitaal, dat stond onder het College van Boedelmeesteren, een Landsinstelling, en ten behoeve van welk armen-ziekenhuis van Landswege bepaalde inkomsten waren aangewezen die afzonderlijk voor dit doel bestemd waren, een niet specifiek Chineesch en zelfs een Gouvernementeel karakter ${ }^{1}$ ).

Eenigszins anders staat het met den Chineeschen Raad en de bezittingen van dit College. Is ook in den ouden tijd het rechtskarakter daarvan als dat van een Landsinstelling geweest, steeds heeft deze een specifiek Chineesch karakter gedragen, zoo wat samenstelling als wat taak betrof, en zelfs is in de $19^{\text {de }}$ eeuw de Chineesche Raad hoe langer hoe scherper als een eigen rechtspersoon erkend, als zoodanig landerijen op eigen naam bezittend, en een eigen fonds beheerend, wel is waar min of meer onder Regeeringstoezicht, doch zób op zich zelf steunend, dat in het geval van het land Slipi, zelfstandig een rechtsgeding tegen dien Raad is gevoerd door het Landscollege van Boedelmeesteren.

Hierbij is wel in het oog te houden, dat een van de hoofdzorgen van dien Chineeschen Raad steeds is geweest die voor de openbare begraafplaatsen van den eigen landaard, en dat de gelden, waaruit het fonds is samengesteld, zoo goed als geheel uit de eigen begrafenisgelden daarvan zijn voortgevloeid; het tegenwoordig reglement wijst dit mede uit.

Het komt mij daarom voor, dat de Chineesche Raad thans te beschouwen is als een op openbaar gezag ingesteld of erkend zedelijk lichaam, eene openbare instelling waaraan van Regeeringswege in het belang der Bataviaansche Chineesche gemeente een afzonderlijk bestaan is verleend, welker onafhankelijkheid alleen verminderd wordt door invloed en toezicht, door de Regeering aan het Gewestelijk bestuur voorbehouden. En voorts: dat van naasting der aan den Chineeschen Raad toebehoorende bezittingen door den Lande alleen sprake zou mogen zijn bij opheffing van deze eigendommelijke instelling, en dit zou weder

1) Vgl. Kol. Versl. 1849 ad F. bl. 74/5. 
m. i. niet behooren te geschieden, tenzij de doelmatigheid zulks uitdrukkelijk zou medebrengen. ${ }^{1}$ ) Uiteraard staat intusschen vast, dat der Regeering vanouds toekomt het recht van regeling met betrekking tot het fonds van den Chineeschen Raad, ten einde de aanwending der inkomsten en het beheer onder Overheidstoezicht te houden in het belang van het doel, dat het oogmerk is geweest bij den aankoop dezer bezittingen.

Voor zoover de Chineesche Raad zelf erkent, dat bij dit College in beheer zijn vastigheden, zooals tempels, die op naam staan van Toapekong en/of Chineesche Officieren, dan zullen deze, naar het toeschijnt, aan te merken zijn als evenzoovele stichtingen, welke mede onder het beheer van evenbedoeld College staan.

Wanneer het uit den tijd der V. O. I. Compagnie dagteekenend instituut der Chineesche Officieren in den tegenwoordigen tijd op bestuursgebied als verouderd mocht worden beschouwd niet meer passend in de Gemeentelijke decentralisatie noch in het kader der reorganisatie van het Gewestelijk Bestuur, dan zou n. h. v. voor het beheer der hoogergenoemde oude algemeene Chineesche begraafplaatsen en tempels nog steeds een uit het plaatselijk Chineesch-element samen te stellen afzonderlijk college van notabele Chineezen aangewezen zijn te achten, - een Chineesche Raad in nieuwen vorm, van welk lichaam de samenstelling, rechten en plichten alsnog zouden behooren te worden geregeld.

1) Niet onder den Chineeschen Raad staat het Chineesche kerkhof Sentiong baroe bij Kemajoran; dit is gekocht met gelden, bijeengebracht door de Chineezen van de wijk Pasar Senen, en het beheer wordt daarover gevoerd door den aldaar woonachtigen Chineeschen Officier. 